\title{
高効率ガスタービン用高性能 $\mathrm{Ni}$ 基耐熱合金 MGA1400 の開発と実用化
}

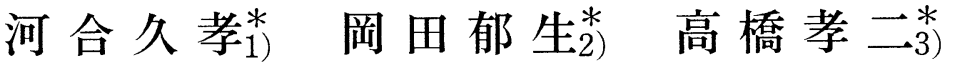 \\ 佐 平 健 彰1) 三橋 章2*
}

\section{1. 緒言}

ガスタービンの熱効率には多くの要因が関与しているが, タービン入口ガス温度 (以下, TIT と称す)の影響が最も大 きい.図1飞示すと扣り TIT は現在 $1500^{\circ} \mathrm{C}$ 級に達して拉 り, これに伴い熱効率も向上している. TIT の上昇はガス タービン高温部品, すなわち燃焼器, タービン動翼・静翼の 冷却構造および使用される材料の改良・開発によるところが 大きい. 高温部品の中でタービン動翼は最も厳しい条件で使 用され, 高い信頼性が要求される部品であり, 高温化に対処 するために，材料面ではより高温強度に優れる $\mathrm{Ni}$ 基耐熱合

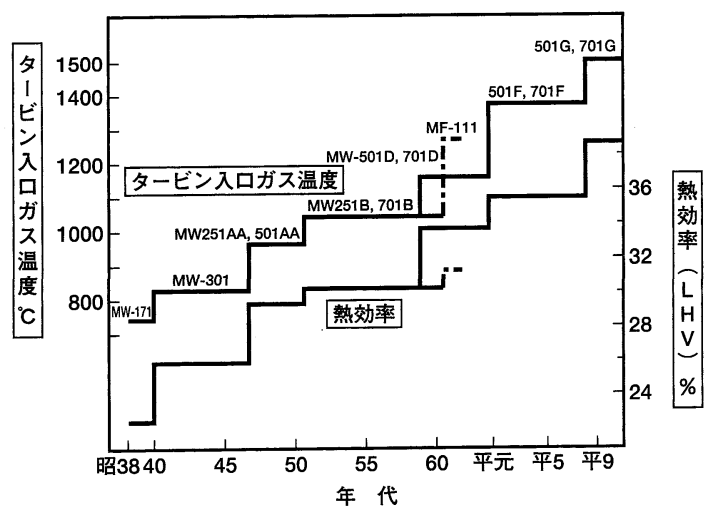

図 1 ガスタービン高性能化の推移.

* 三菱重工業株式会社

技術本部高砂研究所 : 1) 主查(現在 : 高砂製作所）2)主任 高砂製作所 : 3) 主任

** 三菱マテリアル株式会社

総合研究所材料技術研究所 : 1) 室長 (現在 : 桶川製作所) $:$ ) 室長

Development and Application of Advanced Ni-Base Superalloy MGA1400 for High Efficiency Gas Turbine: Hisataka Kawai*, Ikuo Okada*, Kohji Takahashi*, Kensho Sahira**, Akira Mitsuhasi** (*Mitsubishi Heavy Industries, Ltd. ${ }^{* *}$ Mitsubishi Materials Corp.)

1997年 1 月 31 日受理
金が要求されている。しかし，これまで国産合金による実用 ガスタービン動翼はなかった。そこで, 独自の $\mathrm{Ni}$ 基耐熱合 金設計法を用いて，使用条件を考慮に入れ高温強度と耐食性 を兼ね備えた Ni 基耐熱合金 MGA1400 (MITSUBISHI GAS TURBINE ALLOY 1400)を開発し，実用化を図った。

\section{2. 合 金 設 計}

$\mathrm{Ni}$ 基耐熱合金の高温強度は $\gamma^{\prime}$ 相 $\left\{\mathrm{Ni}_{3}(\mathrm{Al}, \mathrm{Ti}, \mathrm{Ta})\right\}$ と炭化 物による析出強化抏よび固溶強化により得られ, 特に $\gamma^{\prime}$ 相 による析出強化の寄与が大きい。

一方, 高温腐食に対しては, $\mathrm{Cr}$ の添加が非常に有効であ る.よって，高温強度と耐食性に優れる合金を得るために は，その組成を $\mathrm{Al}$ 等 $\gamma^{\prime}$ 相形成元素と $\mathrm{Cr}$ を多くすれば良い ことになる.

しかし，両元素を多く添加すると， $\sigma$ 相等の脆化相が生成 するため $\mathrm{Al}$ 等 $\gamma^{\prime}$ 相形成元素と $\mathrm{Cr}$ 添加量のバランスが重要 で，これを十分念頭に拈いて合金設計を行ら必要がある.

上述の考えに基づく $\mathrm{Ni}$ 基耐熱合金設計法は図 2 に示すと 扣りである。

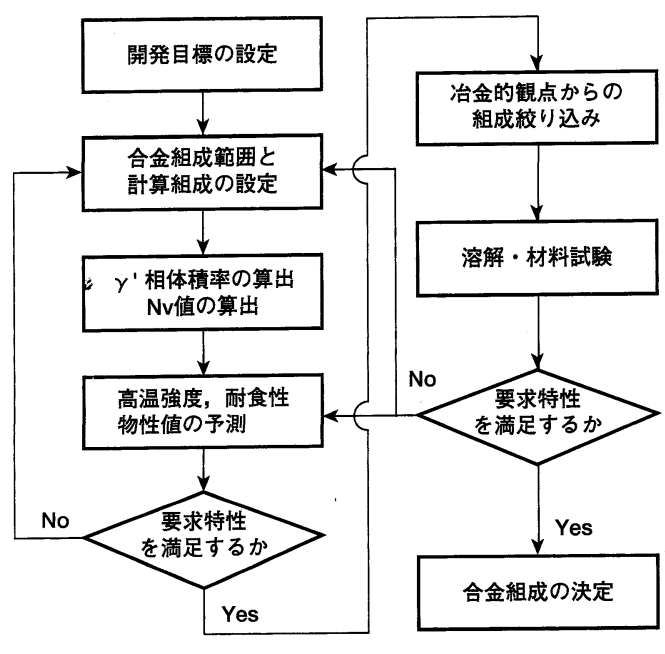

図 2 合金設計法. 


\section{（1）開発目標と合金組成範囲の設定}

最初にクリープ破断強度等合金開発目標に対して設定した 範囲内の合金組成について以下の計算や材料特性の予測を電 算機により行った。合金特性の日標は $\mathrm{Ni}$ 基耐熱合金 IN738LCに比べ以下のと打りである.

(a) 応力 $140 \mathrm{MPa}$, 時間 $50000 \mathrm{~h}$ でのクリープ破断耐用温 度が， $25^{\circ} \mathrm{C}$ 以上優れていること。

(b) 耐食/耐酸化性が同等以上であること.

(c) 鋳造性が同等以上であること.

（2） $\gamma^{\prime}$ 相体積率と $\mathrm{N}_{\mathrm{v}}$ 値の計算

平衡相計算を行い $\gamma^{\prime}$ 相組成, $\gamma$ 相組成牤よび $\gamma^{\prime}$ 相体積率 を算出する。この計算には $\gamma^{\prime}$ 相打よび $\gamma$ 相への各合金成分 分配比が不可欠であるが，本合金設計法では，透過型電子顕 微鏡によるEDS 分析 (Energy Dispersive Spectrometer)を 行い $\gamma^{\prime}$ 相特よび $\gamma$ 相の化学組成に関する実験データを取得 しより精度を高め相計算を行った。

また， $\mathrm{Ni}$ 基耐熱合金のクリープ破断性質 $\left(980^{\circ} \mathrm{C}-150\right.$ $\mathrm{MPa}$ ) と $\gamma^{\prime}$ 相体積率(計算值)の間には図 3 亿示すよらな関係 が別途実施した試験によって明らかになったので，これを考 虑して $\gamma^{\prime}$ 相体積率を $50 \mathrm{vol} \%$ 以上 $60 \mathrm{vol} \%$ 以下にとなるよ ら設定した。

$\gamma$ 相の化学組成(計算値)を基に式 (1)により $\gamma$ 相の平均電 子空孔濃度を算出し，2.42以下となる合金組成を選定した。

$$
N_{\mathrm{v}}=\Sigma\left(E_{\mathrm{i}} \times A_{\mathrm{i}}\right)
$$

ここで, $E_{\mathrm{i}}$ は $\mathrm{i}$ 元素の電子空孔濃度で， $A_{\mathrm{i}}$ は $\mathrm{i}$ 元素の原 子分率である。

\section{（3）各種特性の予測}

次に, 各合金組成を基に, クリー プ破断強度 $\left(760^{\circ} \mathrm{C}\right.$, $\left.870^{\circ} \mathrm{C}, 980^{\circ} \mathrm{C}\right)$, 引張強度 $\left(R T, 650^{\circ} \mathrm{C}, 870^{\circ} \mathrm{C}\right.$ 等), 物性値 (比 重, 熱定数等) 括よび耐食性の予測を行った。こ饥ら特性の 予測には，既存の $\mathrm{Ni}$ 基耐熱合金の各種データを基に統計的 手法により重回㷌式を作成しこれを用いた。

以上の手順により，電算機上で要求特性を満足する合金組 成を抽出し，さらに治金的観点から10種類以下に合金組成 を絞込み，これら合金を溶製の上試験片を作製し，各種特性

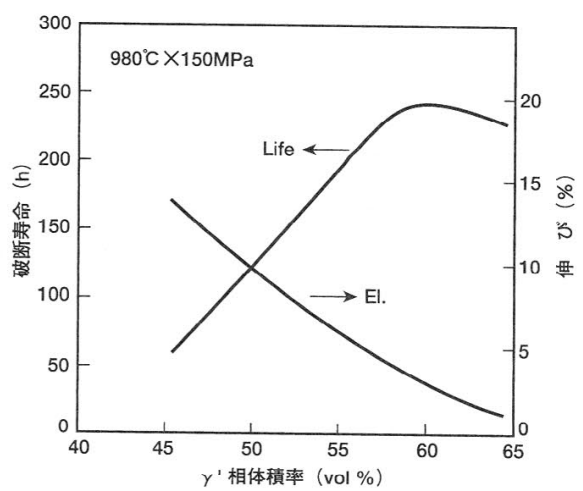

図 $3 \gamma^{\prime}$ 相体積率とクリープ破断性質の関係.
の評価を行った．このルーチンを繰返し，最終的に最もバラ ンスが取れ優れた特性を有する合金組成を決定した。

\section{3. 開発合金の特性}

各種特性の評価・検討によりガスタービン動翼用 $\mathrm{Ni}$ 基耐 熱合金として決定した合金の特性を述べる。

合金組成の特徵は，Cr 量を約 $14 \%$ とし，また， $\gamma^{\prime}$ 相形成 元素である $\mathrm{Al}, \mathrm{Ti}$, 拉よび Ta 量の合計を約 $11 \%$ とし，かつ $\mathrm{A} 1 / \mathrm{Ti}$ 比を 1 以上として $\gamma^{\prime}$ 相体積率を約 $56 \mathrm{vol} \%$ と高めた。 同時に固溶強化元素である Mo と W 量の合計を約 $6 \%$ と多 くした。

熱処理後のミク口組織は図 4 に示すと扮り鋳造合金として 通常のデンドライト状組織を呈して拈り，大きさ約 $0.7 \mu \mathrm{m}$ のく形状の $\gamma^{\prime}$ 相と大きさ $0.1 \mu \mathrm{m}$ 以下の球状の $\gamma^{\prime}$ 相が均一 微細に析出していた.

開発合金の引張性質 $\left(R T, 650^{\circ} \mathrm{C}\right)$ は IN738LC に比べ, 強 度はやや高く，また延性は同等で伸び，絞りともに $5 \%$ 以上 を有し良好であった。 $800^{\circ} \mathrm{C} ら 51000^{\circ} \mathrm{C}$ の温度範囲で実施し たクリープ破断試験の結果を図 5 に示す。本開発合金は IN738LC に比ベてクリープ破断強度が高く, リリープ破断 耐用温度 $(140 \mathrm{MPa}-50000 \mathrm{~h})$ は約 $30^{\circ} \mathrm{C}$ 上昇して拈り, 開発目 標を達成していた。李た, 疲労特性も良好であった。

腐食性成分である $\mathrm{S}, \mathrm{Na}$ 抢よび V を微量添加した燃料を 用いて燃焼ガスによる腐食試験を $850^{\circ} \mathrm{C}$ 打よび $1000^{\circ} \mathrm{C} て ゙$ 実施 した、その結果, 図6に示すと打り開発合金はいずれの温度 に打いても重量変化が少なく, IN738LCより優れた耐食性 を示した。

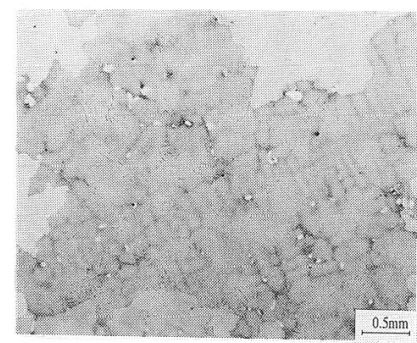

(a) 光学顕微鏡組織

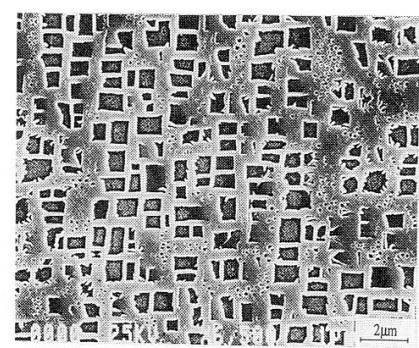

(b) 走査形電子顕微鏡組織
㘠 4 開発合金のミク口組織.

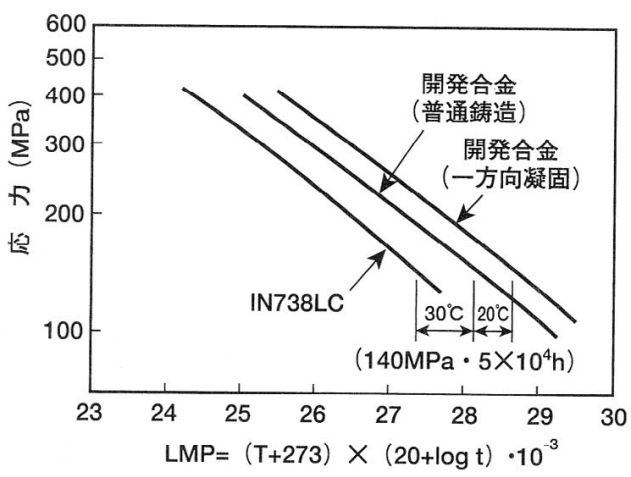

図 5 開発合金のクリープ破断強度. 


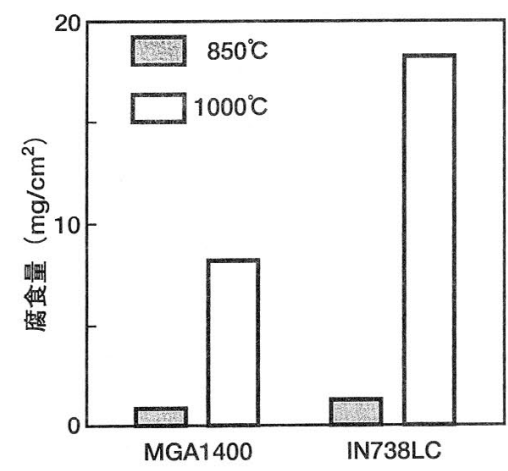

図 6 MGA1400 合金の燃焼ガス雲囲気下での耐食性. (S0.5\%, Na0.1 ppm, V0.1 ppm を灯油に添加， 試験時間 : $280 \mathrm{~h}$ )

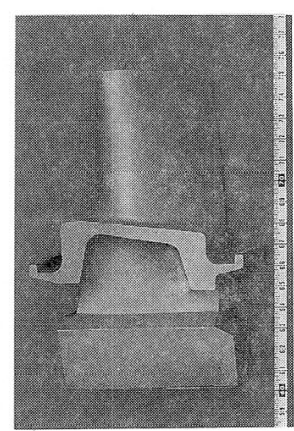

MF221形1段動翼 (試作筫)

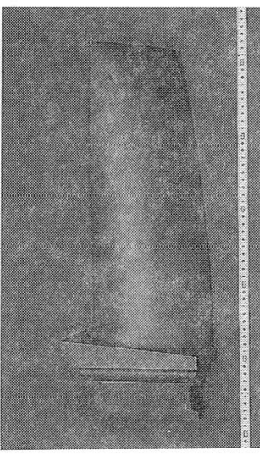

501DAS形3段動翼 (試作翼)

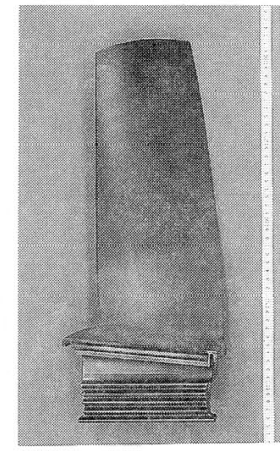

501DAS形3段動翼 (2年使用後)
図 7 普通鋳造翼の外観状況

\section{4. 開発合金の実用化状況}

以上のと物り開発合金はガスタービン動翼材として良好な 特性を有し, クリープ破断強度, 疲労特性, 耐食性等材料特 性はIN738LCより優れていることが判明した。そこで，本 開発合金を用いて普通鋳造翼を試作し特性を評価した。

試作した普通鋳造翼のうち代表例としてTIT $1250^{\circ} \mathrm{C}$ 級 MF221 形ガスタービンの 1 段動翼と 501DAS 形ガスタービ ンの 3 段動翼の外観状沅を図 7 に示す。試作翼に関し, 浸 透探傷扣よび X 線透過試験等非破壊検查を実施した。その 結果，鋳造割れ等鋳造欠陥は認められず，本合金は鋳造性に 問題ないことを確認した。

試作翼より試験片を採取し，ミクロ組織，引張扣よびクリ ープ破断試験を実施した結果，先に述べた材料特性と同等で あることを確認した。以上のと扣り，翼材に打いても良好な 材料特性が得られたので, 501DAS 抗よび MF221 形ガスタ 一ビン動翼として実機に組込久使用中でめる。そとて, 約 2 年の実機使用後に動翼の切断調査を行い, 良好な特性を有 していることを確認した。この結果を踏ま光て, TIT $1500^{\circ} \mathrm{C}$ 級 $501 \mathrm{G}$ 形ガスタービンの後方動翼として適用した.

\section{5. 一方向凝固合金の開発と実用化状況}

上述のと扣り開発した普通鋳造合金は優れた特性を有し，

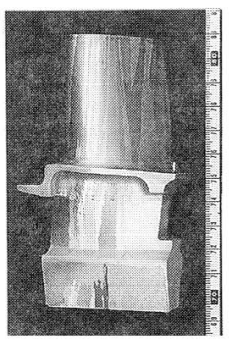

MF111形1段動翼 (試作翼)

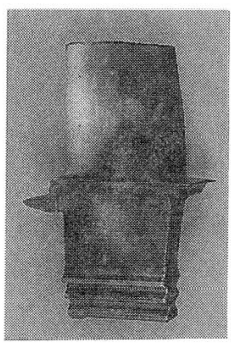

MF111形1段動翼 (2年使用後)

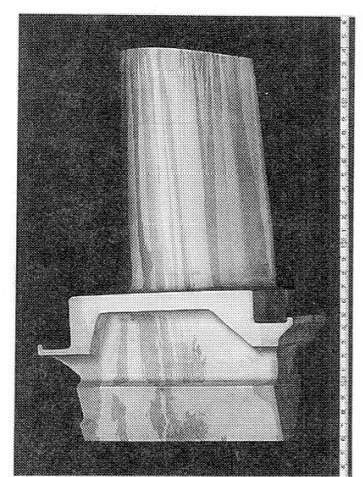

701F形1段動翼

(試作翼)
図 8 一方向凝固翼のマクロ組織之使用後の外観状況.

実機使用に颃いても問題ないことを確認した.

そこで，上述の合金をべースに一方向凝固合金を開発し た。開発した一方向凝固合金は普通鋳造合金より図 5 に示

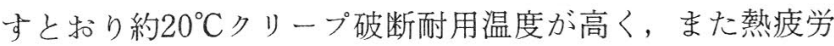
強度は約 1 析向上寸ることを確認した.

次に，当社 TIT $1250^{\circ} \mathrm{C}$ 級 MF111 形执よび TIT $1350^{\circ} \mathrm{C}$ 級 $701 \mathrm{~F}$ 形ガスタービンの 1 段動翼を試作した。試作翼のマク 口組織は図 8 亿示すと扣り良好であり，非破壞検查の結果も 問題なく, また動翼から採取した試験片のミク口組織, 引張 性質牤よび》リープ破断性質は, 開発合金の一方向凝固試験 片鋳造材のそれらと同等であることを確認した。

以上の結果を踏を光，さらに実機製作工程に対する健全性 も検証の上, 平成 6 年 1 月より MF111 形和よび $701 \mathrm{~F}$ 形ガ スタービンの 1 段動翼として使用中であり，図 8 に示すと 扣り，2 年後も良好な性状を有していることを確認した。

さらにTIT $1500^{\circ} \mathrm{C}$ 級 $501 \mathrm{G}$ 形ガスタービンの 1, 2 段動翼 として適用した。

\section{6. 結言}

ガスタービンの高温化に対処するため, 独自の $\mathrm{Ni}$ 基耐熱 合金設計法を用いて，高温強度と耐食性に優れる $\mathrm{Ni}$ 基耐熱 合金MGA1400を開発した。

本開発合金を用いて普通鋳造法によりガスタービン動翼を 試作·評価した結果，良好な材料特性が確認され，現在 MF221 形和よび 501DAS 形ガスタービンの動翼として使用 中である、また，本開発合金をべースに一方向凝固合金を開 発し，さらに高温強度が向上することを確認した。そして MF111 形扣よび 701F 形ガスタービンの動翼として一方向 凝固翼も使用中である.さらに $501 \mathrm{G}$ 形ガスタービンの高温 部品にも適用した。な拉, 本開発合金は国内で開発され, 実 用化された唯一のガスタービン動翼材である。

\section{7. 特 許}

特願平 3-183056, 特願平 4-187530等, 国内外に 7 件出願 済. 